\title{
PENGARUH MUROTTAL TERHADAP PENURUNAN TINGKAT NYERI IBU BERSALIN KALA I FASE AKTIF DI RSUD dr. ZAINOEL ABIDIN
}

\author{
Wirna Hildayati ${ }^{1}$, Siti Hasanah ${ }^{2}$, Evi Kurniawati ${ }^{3}$ \\ 1,2,3 Kampus STIKes Muhammadiyah Aceh, Indonesia, Indonesia
}

\begin{abstract}
Labor pain can cause hyperventilation. This situation will stimulate an increase in catecholamines which can cause obstruction in the strength of uterine contractions such as uterine inertia. The condition can cause fetal distress and maternal death during childbirth. Monitoring and intervention of labor pain in the first stage, especially in the active phase is very important, because it determines whether a mother can undergo a normal delivery or must given an intervention because of severe pain. One of the distraction techniques that can be used is murottal Al-Qur'an. Distraction is an act of diverting the pain experienced by doing something else. One of them is listening to murottal Al-Qur'an. The purpose of the research is to describe the effect of murottal on reducing the level of maternal pain during the active phase of the first stage of labor in dr. Zainoel Abidin hospital. This research is a quantitative research, where the research design used is Quasi Experimental Design with One Group Pretest-Postest. The population is all mothers who give birth during the Active phase of first stage totaling 30 people. In this study, before the intervention the average pain scale was 3.00 with standar deviation of 0.830 . After the intervention the average pain scale was 1.67 with standar deviation of 0.547 with an average difference of 1.33 . The result show that murrotal has significantly effect on reducing the level of maternal pain in the active phase of first stage at dr. Zainoel Abidin hospital with p-value 0.001. the conclusion is it was suggested to midwife apply murottal al-qur'an services to intrapartum patients to reduce labor pain levels.
\end{abstract}

Keywords : murottal; labor pain 


\section{PENDAHULUAN}

Persalinan merupakan proses alami yang akan berlangsung dengan sendirinya, tetapi dalam proses persalinan tidak lepas dari beberapa penyulit membahayakan ibu maupun janin sehingga memerlukan pengawasan dan pertolongan yang tepat serta adanya fasilitas memadai. Salah satu faktor pendukung kelancaran persalinan adalah power/his, dimana kontraksi yang baik dapat mendorong janin keluar rahim melalui jalan lahir. Kontraksi persalinan yang baik dimana frekuensi, intensitas, dan durasinya cukup untuk pembukaan servik. Kontraksi uterus di rasakan nyeri oleh semua ibu bersalin sehingga dapat mempengaruhi psikologis ibu dalam menghadapi persalinan (Netty, 2013)

Nyeri saat persalinan merupakan kondisi fisiologis yang dialami oleh hampir semua ibu bersalin. Ibu mulai merasakan sakit atau nyeri pada saat persalinan kala I fase aktif. Dalam fase ini kebanyakan ibu merasakan sakit yang hebat karena kegiatan rahim mulai lebih aktif, pada fase ini kontraksi semakin lama semakin kuat dan semakin sering. Stres atau rasa takut secara fisiologis dapat menyebabkan kontraksi uterus menjadi semakin terasa nyeri dan sakit dirasakan. Kondisi tersebut membuat uterus semakin tegang sehingga aliran darah dan oksigen kedalam otototot uterus berkurang karena mengecil dan menyempit akibatnya rasa nyeri tidak dapat dihindari (Judha et al., 2012)
Menurut Data Kementerian Kesehatan Republik Indonesia (Kemenkes RI) tahun 2019, jumlah ibu bersalin tercatat sebanyak 5.050 .637 orang dan jumlah kelahiran di Indonesia diperkirakan naik 20\%. Menurut profil kesehatan Indonesia tahun 2018 Angka Kematian Ibu (AKI) di Indonesia mencapai 305 per100.000 kelahiran hidup pada tahun 2015, ini mengalami penurunan dibanding tahun 2012 sebesar 359 per 100.000 kelahiran hidup. Dan target penurunan angka kematian pada tahun 2030 sebesar 131 per 100.000 kelahiran hidup (Kemenkes RI, 2019)

Jumlah ibu bersalin di RSUD dr. Zainoel Abidin pada tahun 2019 sebanyak 844 ibu sedangkan pada tahun 2020 sebanyak 526 ibu, data tersebut menunjukkan bahwa terjadi penurunan jumlah dalam persalinan. Dimana selama proses persalinan ibu yang mengalami tingkat nyeri berbeda-beda.

Menurut Ratnawati dan Dharmanigrum (2011) dari 32 ibu bersalin kala I fase aktif, sebagian besar (59,37\%) mengalami nyeri persalinan. Hal ini sesuai dengan teori Potter \& Perry (2005) mengatakan bahwa nyeri yang paling dominan dirasakan pada saat persalinan yaitu selama kala I persalinan. Secara fisiologis nyeri persalinan mulai timbul pada persalinan kala I fase laten dan fase aktif.(Sri Ratnawati et al., 2011)

Nyeri persalinan dapat menyebabkan timbulnya hiperventilasi sehingga kebutuhan oksigen meningkat, 
kenaikan tekanan darah, dan berkurangnya motilitas usus serta vesikaurinaria. Keadaan ini akan merangsang peningkatan katekolamin yang dapat menyebabkan gangguan pada kekuatan kontraksi uterus sehingga terjadi inersia uteri mengakibatkan (28\%) gawat janin atau fetal distress, $37 \%$ inersia uteri dapat berakibat kematian ibu saat melahirkan dan kenaikan tekanan darah yang menyertai persalinan menyebabkan bahaya bagi ibu, akibatnya dapat meningkatkan risiko hipertensi (12\%), preeklampsiaa (10\%) atau eklampsiaa (5\%). peningkatan tekanan darah salah satu penyebab kematian ibu yang menduduki peringkat ketiga.(Mose et al., 2018)

Sementara menurut profil kesehatan Aceh (2018) angka kematian ibu dilaporkan sebanyak 139 per 100.000 kelahiran hidup, kematian ibu di Aceh kembali menunjukkan peningkatan pada tahun 2019 menjadi 172 per 100.000 lahir hidup dengan jumlah kematian sebanyak 157 kasus, jika dilihat menurut Kabupaten angka kematian ibu yang terendah di pidie sebanyak 1 kasus dan yang tertinggi Bireun sebanyak 16 kasus dan di ikuti Aceh Utara sebanyak 25 kasus. (Provinsi Aceh., 2018)

Penanganan dan pengawasan nyeri persalinan terutama kala I fase aktif sangat penting, karena sebagai penentu apakah seorang ibu dapat menjalani persalinan normal atau diakhiri dengan suatu tindakan karena adanya penyulit diakibatkan nyeri yang sangat hebat (Hernawati, 2009). Berbagai metode telah digunakan untuk mengurangi dan menghilangkan nyeri persalinan baik secara farmakologis menggunakan analgesia dan analgesia opiod, analgesia regional, ILA (intratchecal labor analgesia) maupun non farmakologis secara relaksasi dan hipnotis, imajinasi terbimbing, masase dan terapi terapeutik, akupuntur, posisi dan postur, hidroterapi dan murottal Al-qur'an (Sulistyo \& Suharti, 2015)

Salah satu tekhnik distraksi yang bisa digunakan yaitu murottal Al-qur'an. Distraksi merupakan tindakan mengalihkan rasa nyeri yang dialami dengan melakukan hal lain, sehingga pasien tidak berfokus terhadap rasa nyeri tersebut. (Handayani et al., 2016) Diantaranya adalah dengan mendengarkan murottal Al-Qur'an. Murottal Al-qur'an merupakan rekaman suara Al-Qur'an yang di lagukan oleh seorang Qori atau pembaca Al-Qur'an (Fikriya et al., 2016) Walaupun manfaat mendengarkan murottal Al-Qur'an tidak sehebat ketika membaca AI-Qur'an secara lisan, tapi sudah cukup mempengaruhi kerja otak. Ketika diperdengarkan Murottal Al-Qur'an, maka neuropeptide akan diproduksi oleh otak sehingga mengurangi ketegangan emosi, memberikan rasa nyaman dan rileks. (Setianto, 2017)

Lantunan Al-Qur'an secara fisik mengandung unsur suara manusia, suara manusia merupakan instrumen 
penyembuhan menakjubkan dan alat yang paling mudah di jangkau. Suara dapat menurunkan hormon-hormon stres, mengaktifkan hormon endorfin alami, meningkatkan perasaan rileks, dan mengalihkan perhatian dari rasa takut, cemas dan tegang, memperbaiki sistem kimia tubuh sehingga menurunkan tekanan darah serta memperlambat pernafasan, detak jantung, denyut nadi, dan aktivitas gelombang otak. Laju pernafasan yang lebih dalam atau lebih lambat tersebut sangat baik menimbulkan ketenangan, kendali emosi, pemikiran yang lebih dalam dan metabolisme yang lebih baik. (Handayani et al., 2016)

Terapi murottal menggunakan tape recorder, pita kaset bacaan al-qur'an dan ear phone yang terdiri surah Maryam yang lebih mudah dihafal dan familiar dalam pendengaran orang, surah Maryam juga menggambarkan prose persalinan yang dimulai dengan rasa sakit dan dalam ilmu kebidanan yang disebut kontraksi karna nyeri persalinan. Maryam mulai merasakan rasa sakit kontraksi disebabkan oleh desakan janin,. Rasa yang begitu hebat membuatnya nyaris putus asa. Keadaan dirinya yang sendiri, jauh dari keluarga, tanpa seorang pun di dekatnya. Maryam pun mengeluarkan seluruh keluh kesahnya. Keputusasaanya karena rasa sakit yang terus datang silih berganti. Dia (Jibril) datang kepada Maryam yang sedang sedih untuk menghibur dan menenangkan rasa kekhawatirannya, serta memberitahu kepada Maryam bahwa Allah SWT telah mengalirkan sebuah anak sungai untuknya.

Berdasarkan studi pendahuluan yang telah dilakukan peneliti kepada 10 ibu bersalin kala I fase aktif di RSUD dr. Zainoel Abidin Banda Aceh, dilakukan observasi dan menilai skala nyeri berdasarkan skala intensitas numeric (numeric rating scale) didapatkan data hasil observasi bahwa 6 ibu tingkat nyeri berada pada skala 7-9 yaitu nyeri berat ibu dapat menunjukkan lokasi nyeri tetapi tidak dapat mendeskripsikannya, 2 ibu berada pada skala nyeri 10 yaitu sangat berat tidak dapat terkontrol ditandai dengan ibu berteriak keras, tidak dapat mengikuti perintah dan tidak dapat menunjukkan lokasi nyeri, dan 2 ibu mengatakan bahwa tingkat nyeri berada pada skala 4-6 yaitu nyeri sedang, ditandai dengan ibu mendesis dan dapat menunjukkan lokasi nyeri.

Murottal qur'an pada ibu bersalin sebelumnya tidak pernah dilakukan untuk mengurangi nyeri ibu bersalin di RSUD dr. Zainoel Abidin, pengurangan rasa nyeri yang dilakukan selama ini dengan tekhnik relaksasi. Dengan adanya data tersebut, peneliti tertarik untuk melakukan penelitian "Pengaruh Murottal Terhadap Penurunan Tingkat Nyeri Ibu Bersalin Kala I Fase Aktif di RSUD dr. Zainoel Abidin Banda Aceh Tahun 2021". 
METODOLOGI PENELITIAN

Penelitian ini merupakan penelitian kuantitatif, dimana rancangan penelitian yang dipakai adalah Quasi Experimental Design dengan one group pre tets-post test design. Pertama dilakukan pengukuran, kemudian dikenakan perlakuan untuk jangka waktu tertentu lalu dilakukan pengukuran untuk kedua kalinya (Nursalam, 2015).

Adapun sampel dalam penelitian ini adalah ibu bersalin kala I fase aktif sebanyak tiga puluh responden. Prosedur dan teknik pengambilan sampel yang dilakukan adalah dengan menggunakan consecutive sampling. Penelitian ini bertujuan untuk mengetahui pengaruh murottal al-qur'an terhadap penurunan nyeri ibu bersalin kala I fase aktif dengan mendengar murottal qur'an surah Maryam selama 30 menit menggunakan headset blutot yang disambungkan ke handphone (HP) Samsung dan besar volume 5 .

\section{HASIL PENELITIAN DAN BAHASAN}

\section{Analisa Univariat}

Analisa univariat pada penelitian ini dapat dilihat dari tabel distribusi frekuensi tingkat nyeri pada ibu bersalin sebelum dilakukan intervensi mendengarkan murrotal pada ibu bersalin kala I fase aktif dan sesudah intervensi sebagai berikut
Tabel .1 Distribusi Frekuensi Tingkat Nyeri Sebelum Intervensi Pada Ibu Bersalin Kala I Fase Aktif di Rumah Sakit Umum dr. Zainoel Abidin

\begin{tabular}{|c|c|c|c|}
\hline No & $\begin{array}{ll}\text { Nyeri persalinan } \\
\text { sebelum intervensi }\end{array}$ & Jumlah & $\%$ \\
\hline 1 & Nyeri ringan & 10 & $0 \%$ \\
\hline 2 & Nyeri sedang & 10 & $33,3 \%$ \\
\hline 3 & Nyeri berat & 10 & $33,3 \%$ \\
\hline 4 & Nyeri sangat berat & 10 & $33,3 \%$ \\
\hline & Jumlah & 30 & $100 \%$ \\
\hline
\end{tabular}

Berdasarkan tabel.1 dapat diketahui dari 30 responden bahwa tingkat nyeri ibu bersalin sebelum intervensi berada pada nyeri sedang 10 (33,3\%), nyeri berat $10(33,3 \%)$ dan nyeri sangat berat $10(33,3 \%)$.

Tabel. 2 Distribusi Frekuensi Tingkat Nyeri Sesudah Intervensi Pada Ibu Bersalin Kala I Fase Aktif di Rumah Sakit Umum dr. Zainoel Abidin

\begin{tabular}{llcc}
\hline No & $\begin{array}{l}\text { Nyeri persalinan } \\
\text { sesudah } \\
\text { intervensi }\end{array}$ & Jumlah & $\%$ \\
\hline 1 & Nyeri ringan & 11 & $36,7 \%$ \\
\hline 2 & Nyeri sedang & 18 & $60 \%$ \\
\hline 3 & Nyeri berat & 1 & $3,3 \%$ \\
\hline & Jumlah & 30 & $100 \%$ \\
\hline & Berdasarkan & tabel. $\quad 2$ & dapat
\end{tabular}

diketahui dari 30 responden tingkat nyeri ibu bersalin sesudah intervensi berada pada nyeri sedang $18(60 \%)$, nyeri ringan $11(36,7 \%)$, dan nyeri berat 1 (3,3\%). Maka dapat disimpulkan bahwa sebagian besar nyeri ibu bersalin sesudah intervensi mengalami penurunan. 


\section{Analisa Bivariat}

Tabel. 3 Perbedaan Rata-Rata Skala Nyeri Sebelum Intervensi dan Sesudah Intervensi Pada lbu Bersalin Di RSUD dr. Zainoel Abidin

\begin{tabular}{|c|c|c|c|c|c|c|}
\hline $\begin{array}{l}\mathrm{N} \\
\mathrm{O}\end{array}$ & $\begin{array}{c}\text { Skala } \\
\text { Nyeri } \\
\text { Persalinan }\end{array}$ & Mean & SD & SE & $\begin{array}{c}\text { Selisih } \\
\text { rata- } \\
\text { rata }\end{array}$ & $\begin{array}{c}\mathrm{p}^{-} \\
\text {value }\end{array}$ \\
\hline 1 & $\begin{array}{c}\text { Nyeri } \\
\text { sebelum } \\
\text { intervensi }\end{array}$ & 3.00 & $\begin{array}{l}0.8 \\
30\end{array}$ & $\begin{array}{c}0.15 \\
2\end{array}$ & 1,33 & $\begin{array}{c}0.00 \\
1\end{array}$ \\
\hline 2 & $\begin{array}{c}\text { Nyeri } \\
\text { sesudah } \\
\text { intervensi }\end{array}$ & 1,67 & $\begin{array}{l}0.5 \\
47\end{array}$ & $\begin{array}{c}0.10 \\
0\end{array}$ & & \\
\hline
\end{tabular}

Berdasarkan tabel. 3 menunjukkan bahwa hasil penelitian sebelum dilakukan intervensi rata-rata skala nyeri sebesar 3,00 dengan deviasi 0,830 , setelah dilakukan intervensi maka rata-rata skala nyeri menurun 1,67 dengan deviasi sebesar 0,547. Hasil statistik menunjukkan bahwa terdapat pengaruh yang signifikan terhadap penurunan skala nyeri ibu bersalin dengan $p$-value 0,001 dengan selisih rerata yaitu 1.33 .

Hasil penelitian eksperimen terhadap responden tentang pengaruh murottal terhadap penurunan tingkat nyeri ibu bersalin kala I fase aktif di RSUD dr. Zainoel Abidin Tahun 2021, berdasarkan analisis statistik menggunakan uji-T menunjukkan bahwa terdapat pengaruh terhadap penurunan tingkat nyeri ibu bersalin kala I fase aktif dengan P-value < $0,05(0,001)$.

Setelah diberikan murottal AlQur'an didapatkan bahwa intensitas nyeri persalinan kala I fase aktif menurun. Hasil penelitian ini sesuai dengan penelitian
Handayani, Fajarsari, dkk (2014) terdapat perbedaan rata-rata penurunan intensitas nyeri persalinan kala I fase aktif sebelum dan sesudah dilakukan terapi murottal AlQur'an dengan p-value (0,000). (Handayani et al., 2016)

Sesuai juga dengan penelitian Hidayah, Maliya, dan Nugroho (2013) yang menyatakan bahwa teknik distraksi berupa mendengarkan murottal Al-Qur'an mampu meringankan dan menenangkan perasaan pasien dari rasa sakit, didapatkan hasil bahwa terjadi penurunan nyeri pada pasien post operasi fraktur ekstremitas setelah diberikan terapi murottal Al-Qur'an dengan P-value 0,001. (Hidayah et al., 2013)

Terapi berupa suara dapat mengatur hormon-hormon yang berhubungan dengan stres antara lain $\mathrm{ACTH}$, prolaktin dan hormon pertumbuhan serta dapat meningkatkan kadar endhorpin sehingga dapat mengurangi nyeri (Campbell, 2015). Menurut Potter \& Perry (2005), terapi berupa musik atau suara harus didengarkan minimal 15 menit untuk memberikan efek terapeutik, sedangkan menurut Yuanitasari (2017) durasi pemberian terapi musik atau suara selama 10-15 menit dapat memberikan efek relaksasi. Intensitas suara yang rendah antara 50-60 desibel menimbulkan kenyamanan dan tidak nyeri serta membawa pengaruh positif bagi pendengarnya. Terapi bacaan Al-Qur'an terbukti mengaktifkan sel-sel tubuh dengan mengubah getaran suara menjadi 
gelombang yang ditangkap oleh tubuh, menurunkan stimuli reseptor nyeri dan otak teransang mengeluarkan analgesik opioid natural endogen untuk memblok adenociceptor nyeri. (Yuanita, 2017)

Nyeri persalinan merupakan pengalaman subyektif yang dialami ibu tentang sensasi fisik yang terkait dengan kontraksi uterus, dilatasi dan penipisan serviks serta penurunan janin selama persalinan. Reaksi terhadap nyeri merupakan respon yang sifatnya sangat individual. Nyeri persalinan tergantung reaksi pada kepribadian, kondisi emosional serta tingkat pemahaman pasien, latar belakang kultural, pengalaman sebelumnya dan tingkat intensitas nyeri seseorang.

Pada penelitian ini kecemasan bukanlah salah satu penyebab utama yang dapat menimbulkan nyeri hebat saat persalinan karena nyeri yang dirasakan pada persalinan berbeda-beda pada satu wanita ke wanita yang lain. Banyak faktor predisposisi yang dapat mengurangi atau meningkatkan derajat nyeri persalinan yang dirasakan seorang wanita termasuk pengalaman dahulu mengenai nyeri, pengetahuan mengenai persalinan, latar belakang budaya dan persepsi seseorang itu sendiri sebagai seorang yang dapat atau tidak mampu menghadapi nyeri. (Simkin, P., Whalley, J., \& Keppler, 2008)

Tingkat daya tahan tubuh dan penerimaan rasa nyeri pada setiap orang berbeda. Penerimaan rasa nyeri tersebut dipengaruhi oleh keadaan fisik individu, psikologis dan kondisi budaya. Reaksi terhadap rasa nyeri juga berbeda pada setiap wanita. Budaya, jenis kelamin, tingkat kepercayaan, dan umur dapat memberikan effek terhadap asumsi rasa nyeri dan reaksi terhadap nyeri tersebut. (Beigi et al., 2010)

Menurut asumsi peneliti kebanyakan ibu bersalin merasakan nyeri pada kala I fase aktif, dalam fase ini kebanyakan ibu merasakan sakit yang hebat karena kontraksi, kontraksi semakin lama semakin kuat dan semakin sering. Nyeri persalinan yang berat terkadang juga timbul karena intensitas nyeri, pengalaman melahirkan sebelumnya, rasa cemas atau stres dari diri ibu sendiri, tetapi rasa nyeri juga di timbulkan karena semakin lama kontraksi uterus semakin sering terjadi ditambah lagi nyeri akibat dorongan kepala bayi yang semakin turun membuka jalan lahir yang menambah rasa sakit ibu bersalin.

Kondisi tersebut yang sering kali membuat ibu menyerah dan berkata tidak bersedia untuk melanjutkan proses persalinannya karena rasa sakit berkepanjangan yang terus dialami ibu, rasa nyeri persalinan jika dibiarkan terus menerus bisa menyebabkan kecemasan, kegelisahan dan rasa takut menghadapi proses persalinan. Nyeri persalinan bisa di kurangi sedikit intensitasnya jika ibu mampu melatih dirinya untuk menjadi rileks.

Kecemasan adalah hal fisiologis terjadi pada proses persalinan akibat nyeri 
yang dirasakan, namun apalagi nyeri persalinan tidak ditangani segera akan memperburuk proses persalinan. Nyeri persalinan, rasa takut dengan pengalaman sebelumnya dapat di kurangi atau diredakan dengan berbagai metode sebagai alternatif bisa menggunakan beberapa cara tekhnik relaksasi seperti terapi lantunan al-qur'an, maupun menggunakan tekhnik distraksi pernafasan untuk membantu ibu menjadi sedikit lebih rileks sehingga kegelisahaan pada ibu bersalin tidak sampai terjadi.

Eksperimen yang dilakukan oleh Ahmed Elkadi mengungkapkan bahwa pembacaan

Al-Qur'an dapat memunculkan relaksasi pada ketegangan syaraf beserta perubahan-perubahan fisiologis. Peneliti menilai, hanya dengan pembacaan Al-Qur'an saja dapat membuat efek yang baik bagi tubuh, terlebih lagi jika pembacaan Al-Qur'an tersebut diperdengarkan dengan irama yang stabil dan dilakukan dengan tempo yang lambat serta harmonis, maka akan memunculkan ketenangan bagi pendengarnya dan dapat dijadikan penyembuh baik dari gangguan fisik maupun psikis.

Berdasarkan hasil penelitian ini, secara tidak langsung murottal Al-Qur'an dapat dijadikan sebagai penyembuh sakit seperti yang dikatakan oleh Al-kaheel (2012), bahwa Al-Qur'an sebagai penyembuh telah dilakukan dan dibuktikan, orang yang membaca AlQur'an atau mendengarkan akan memberikan perubahan arus listrik di otot, perubahan sirkulasi darah, perubahan detak jantung dan perubahan kadar darah pada kulit.

Mendengarkan Al-Qur'an akan memberikan efek relaksasi, sehingga pembuluh darah nadi dan denyut jantung mengalami penurunan. Terapi bacaan AlQur'an ketika diperdengarkan pada orang atau pasien akan membawa gelombang suara dan mendorong otak untuk memproduksi zat kimia yang disebut neuropeptide. Molekul ini akan memengaruhi reseptor didalam tubuh sehingga hasilnya tubuh merasa nyaman. (Arif Setyo Upoyo, Helwiyah Ropi \& Sitorus., 2011)

Tingkat nyeri yang dialami pada pasien dapat berkurang atau menurun setelah dilakukan murottal qur'an selama 30 menit. Karena mendengarkan bacaan ayat suci al-qur'an lebih bermanfaat, suara al-qur'an bisa meredakan stress dan meningkatkan ketahanan stress, meningkatkan relaksasi, ketenangan, kenyaman dan intensitas nyeri. Saat responden mendengarkan bacaan ayat suci al-qur'an yang didengarkan dengan baik, maka bisa menimbulkan rasa nyaman dan tenang bagi pasien sehingga nyeri dapat berkurang da nada penurunan pada skala nyeri.

Mendengarkan murottal qur'an juga dapat merasakan perubahan secara fisiologis seperti ketenangan jiwa, hal tersebut membuktikan al-qur'an memiliki pengaruh yang sangat kuat pada 
kesehatan terutama untuk menimbulkan perasaan rileks dan nyaman sehingga bisa menurunkan intensitas nyeri.

\section{KESIMPULAN}

Tingkat nyeri yang dialami pada pasien persalinan dapat berkurang atau menurun setelah dilakukan murottal qur'an selama 30 menit. Mendengarkan bacaan ayat suci al-qur'an lebih bermanfaat, suara al-qur'an bisa meredakan stress dan meningkatkan ketahanan stress, meningkatkan relaksasi, ketenangan, kenyaman dan intensitas nyeri. Saat responden mendengarkan bacaan ayat suci al-qur'an yang didengarkan dengan baik, maka bisa menimbulkan rasa nyaman dan tenang sehingga nyeri dapat berkurang.

\section{DAFTAR PUSTAKA}

1. Arif Setyo Upoyo, Helwiyah Ropi, \& Sitorus., R. (2011). Stimulasi Alqur'an Terhadap Nilai GSC pada pasien Stroke Iskemik. IJAS, 1(3).

2. Beigi, N. M. A., Broumandfar, K., Bahadoran, P., \& Abedi, H. A. (2010). Women's experience of pain during childbirth. Iranian Journal of Nursing and Midwifery Research, 15(2), 7782.

https://pubmed.ncbi.nlm.nih.gov/2158 9784

3. Fikriya, K., Ropitasari, \& Yunita, F. A. (2016). Pengaruh Terapi Murottal Al-
Qur'an terhadap Nyeri Persalinan

Kala1 Fase Aktif. Perpustakaan uns.ac.id.

4. Handayani, R., Fajarsari, D., Retno Trisna Asih, D., \& Naeni Rohmah, D. (2016). Pengaruh Terapi Murottal AlQur'an Terhadap Penurunan Intensitas Nyeri Persalinan dan Kecemasaan dalam Persalinan Primigravida Kala I Fase Aktif di RSUD Prof. Dr. Margono Soekardjo Tahun 2014. Jurnal IImiah Kebidanan, $7(1), \quad$ 119-129. http://ojs.akbidylpp.ac.id/index.php/Pr ada/article/viewFile/147/135

5. Hidayah, T. N., Maliya, A., \& Nugroho, A. B. (2013). Pengaruh pemberian murottal al-qur'an terhadap tingkat nyeri pasien post operasi fraktur ekstremitas.

Https://Ejournal.Unisayogya.Ac.Id.

Artikel.

6. Judha, M., Sudarti, \& Fauziah, A. (2012). Teori pengukuran nyeri \& nyeri persalinan. Yogyakarta: Nuha Medika.

7. Kemenkes RI. (2019). Profil kesehatan Republik Indonesia.

8. Mose, J. C., Irianti, S., Maartaadisoebrata, Wirakusumah, F., \& (Eds)., J. S. E. (2018). Hipertensi Dalam Kehamilan. Obstetri Patologi (3rd ed., pp. 95-101). EGC.

9. Netty, I. (2013). Hubungan mobilisasi dini dengan penyembuhan luka post operasi secsio sesarea di ruang rawat gabung kebidanan di RSUD H. Abdul 
Manap Kota Jambi Tahun 2012.

10. Provinsi Aceh., D. K. (2018). Profil Kesehatan Aceh.

11. Setianto, R. (2017). Pengaruh Massage Effleurage Terhadap Pengurangan Rasa Nyeri pada Persalinan Kala I Fase Aktif di Wilayah Kerja Puskesmas Kemalang. Journal Center of Research Publication in Midwifery and Nursing, 1(2), 55-61. https://doi.org/10.36474/caring.v1i2.2 3

12. Simkin, P., Whalley, J., \& Keppler, A. (2008). Panduan Lengkap Kehamilan, Melahirkan dan Bayi. Jakarta: Arcan.

13. Sri Ratnawati, Sunarsih, \& Whike Kristina Dharmaningrum. (2011). Hubungan Antara Paritas dan Nyeri Persalinan pada Kala I Fase Aktif di Bidan Praktek Swasta Eny Juarniaty. Jurnal Penelitian Kesehatan Suara Forikes, 2(3), 152-160.

14. Sulistyo, \& Suharti. (2015). Persalinan tanpa nyeri berlebihan. Jogjakarta. ArRuzz Media.

15. Yuanita, L. (2017). Terapi Musik untuk Anak Balita. Yogyakarta: Cemerlang Publishing. 